\title{
Afghan Refugees: Is International Support Draining Away after Two Decades in Exile?
}

\author{
Rupert Colville
}

\begin{abstract}
Afghanistan holds all the refugee records, both good and bad. However, as the remaining refugees enter their twentieth year in exile, international support for finding a solution to their predicament appears to be dwindling as the Taliban consolidate their hold on Afghanistan while simultaneously alienating much of the outside world. Because of insufficient funding, United Nations High Commissioner for Refugees (UNHCR) has had to curtail voluntary repatriation programs in 1998 and reports a bleak outlook for 1999.
\end{abstract}

\section{Précis}

\begin{abstract}
L'Afghanistan détient tous les records en matière de réfugiés. Les meilleurs et les pires. Or, alors que les derniers réfugiés entament leurvingtième année d'exil, le soutien international de la recherche d'une solution à leur sort semble s'effriter à mesure que les Talibans consolident leur domination sur le pays, tout en se mettant de plus en plus d̀ do le concert des nations. Pour cause de fonds insuffisants, le Haut Commissariat des Nations Unies pour les réfugiés a du réduire ses programmes de rapatriement volontaire sur l'Afghanistan en 1998, et prévoit une conjoncture particulièrement morose pour 1999.
\end{abstract}

Rupert Colville has been UNHCR's Regional Public Information Officer based in Islamabad since October 1996. Before that he spent over four years at UNHCR headquarters in Geneva, starting as editor of the first edition of The State of the World's Refugees, and then as a Public Information Officer and spokesman covering North Africa, the Middle East and South and Central Asia. In all, he has been covering Afghanistan and neighbouring countries for a total of five years.

The opinions expressed in this article do not necessarily reflect the official views of UNHCR.
Small numbers of Afghan refugees began fleeing their country in 1978, when fighting broke out between the Afghan communist government and various rural resistance groups. Within a few months of the 1979 Soviet invasion, the initial trickle turned into a major flood.

By the end of 1980, the Afghans had become the largest single refugee caseload in the world, an unfortunate record that they still hold 18 years later. They haveneverbeen deposed, noteven for a week or a month, from this tragic NumberOnespot-notby the Iraqis, the Bosnians, the Somalis, not even by the Rwandans. For much of the late 1980s, the Afghans constituted just under half of the entireworld's refugee population. In 1990, the number of Afghan refugees peaked at the astronomical figure of 6.2 million (split almost equally between Pakistan and Iran) (Colville 1997, 4).

The Afghans hold a second, somewhat happier, post-World War II refugee record: by October 1998, the total number of refugees who had gone home to Afghanistan had climbed to just under 4.1 million-the largestrepatriation of a single refugee group since UNHCR came into existence, and one of the largestin history (UNHCR 1998d). Of these, 2.7 million Afghan refugees had returned from Pakistan (over 2 million of them with repatriation assistance from UNHCR), and another 1.3 million had returned from Iran (around 570,000 of them assisted) (UNHCR 1998a).

A substantial proportion of the $\mathbf{2 . 6}$ million Afghan refugees still living in Pakistan and Iran have been there for almost two decades. In terms of the length of exile it is not a unique situation-but it is unique in modern times for such a vast number of refugees to have remained outside theirhomecountry for such a long period of time.

Throughout the $1980 \mathrm{~s}$, as the mujahedeen groups fought their war of attrition against the Soviet invaders, the
Afghan refugees won the sympathy of most of the rest of the world, as well as a staggering amount of financial and material support. By the late 1990 s, however, that sympathy and the attendant funds seem to be wearing very thin. The morale of some elements of the refugee population-in particular the educated urban elite, and the non-Pashtun ethnic groups (for the most part living in Iran)-has sunk to an all time low.

During the 1980s, huge amounts of money, and dozens of aid agencies, poured into Pakistan as tented camps were transformed into more than 350 mud-brick refugee "villages" (some of which ended up more like small cities). UNHCR alone has spent over U.S.\$ 1 billion on Afghan refugees in Pakistan since it first began operations there in October 1979 (UNHCR 1998b). The World Food Program (WFP) has spenta further U.S.\$800 million (WFP 1998). Simultaneously, many other actors, including the Pakistan government, other governments and NGOs, were also spending considerable sums on the refugees.

The situation in Iran was somewhat different. Because of the government's fierce independence and its difficult relations with Western donor nations and wealthy Arab nations-all of whom were pumping money into Pakistan-Iran received much less international aid than Pakistan, andbore much of the economic burden of hosting 3 million refugees itself(Colville 1997,46).

In addition to the huge quantities of aid money flowing into Pakistan in the 1980 s, even larger amounts of money were flowing through various channels to fund the various mujahedeen groups fighting against the Afghan communist and Soviet forces. For ten years or more, some western parts of Pakistan resembled a vast international humanitariancum-military bazaar dedicated to the 
successful running of the last, and perhaps decisive, battle of the Cold War.

Unfortunately, as a few wise voices counselled at the time-and many more have noted with hindsight-the money was in many ways not always spent wisely. Beneficiaries included Usama Bin Laden, now perhaps the world's most wanted man, and many other "Afghan Arabs" blamed for religious extremism, subversion, instability and assassinations in countries as diverse as Algeria, Egypt, Bosnia and Chechnya. In addition to external beneficiaries such as these, several favoured mujahedeen groups were able to salt away money and weapons for the express purpose of winning the inevitable power struggle among themselves that would take place once the Soviet army quit the battlefield and the indigenous communist government collapsed (Maley 1998).

The consequences of this unbridled free-for-all have been calamitous, not just for the refugees but for Afghanistan as a whole. Many of the original refugees have been deterred from going back because of the new internal conflicts that broke out following the fall of the Najibullah government in April 1992. And whole new categories of refugees have appeared since then-Kabulis in general, educated women and professionals in particular, and most recently Shia Hazaras from northern and central Afghanistan. The number of these new refugees in no way compares to the number of predominantly rural refugees who fled in the 1980 s, but the chaos and social degradation from which they are escaping may in the end prove even more damaging to Afghanistan's longterm future. Put simply, Afghanistanperhaps more than any other country - cannot afford the current, almost total, brain drain of its relatively small educated urban elite.

\section{Life in Exile}

In terms of survival in exile, the Afghans in Iran and Pakistan have by and large done extremely well. They have shaken off dependency on international aid, and steadily returning home when they feel the time is right for them and their families to do so-despite a seemingly endless conflict between constantly shifting alliances of warring factions, the total breakdown of institutions, a virtually non-existent economy and shattered infrastructure inside Afghanistan.

A fair proportion of the remaining refugees in both countries run thriving businesses. The great majority are now self-sufficient, if often extremely poor with many depending on daily labour at very low wages to survive (British Agencies Afghanistan Group 1996). Nevertheless, the spectre of eternal reliance on international aid-with all its attendant corrosive effect on the refugees' psychological and social well-being - has been avoided (ibid.).

\section{Promoting Self-Reliance in Pakistan}

Although the refugees in Pakistan were officially supposed to live in refugee villages, in practice the Government of Pakistan has been lenient. The Afghan refugees enjoyed freedom of movement, and of settlement. They were allowed to establish and run businesses and to have access to employment and services such as free education and free health care when these were available.

This practice continued until 1995. Since then, the relentless civil war in Afghanistan and the scaling down of international assistance for the Afghan refugees have triggered impatience among some sections of Pakistan's general public as well as an internal debate in political circles on the need to promote a solution to the Afghan conflict which would allow the refugees to repatriate. Nowadays, the climate of compassion and sympathy toward the Afghan refugees is cooling.

In the initial planning of assistance activities, international efforts did not consider the potential for the refugee population to become self-reliant. The lack of planning was possibly exacerbated by the way the program for Afghan refugees developed, with abundant financial resources flowing in from different quarters and the variety of approaches and interests of the hundreds of different agencies and par- ties providing assistance to the refugees.

Against this background, UNHCR and its partners consequently faced numerous problems when they tried to redirect the assistance program after more than a decade of ignoring what Afghan refugees themselves were capable of doing. Not only was there hostility to the idea on the part of the refugee community, who had come to expect an unending round of handouts, but there was also serious resistance from some relief officers who were sceptical about refugees being capable of managing services for themselves.

Direct food assistance for the original refugee caseload, the great majority of whom had become more or less self-sufficient by the early 1990s, was gradually reduced and then finally phased out altogether in September 1995. Vulnerable refugee families and individuals who are unable to support themselvesfor example widows, disabled people and several relatively small waves of new arrivals from Afghanistan-have continued to benefit from targeted assistance (Malha 1997, 9-13).

In both water and health sectors, refugees have gradually become more involved in the management of basic facilities. Through water management committees, refugees now manage some of the water supply schemes. They ensure that systems are run properly, access to the water supply is equitable and scarce water resources are conserved. They also share part of the systems' operational and maintenance costs.

Refugees have also formed health committees that, with additional input from agency and government staff, will hopefully expand the reach of primary health care. The delivery of health care now relies greatly on community workers and animators who disseminate information on major health care activities such as immunization and mother and child care available at the health units. The committees also ensure the collection of financial contributions from refugees receiving health treatment. They have the authority to waive the payment of fees for extremely poor refugees. The health committees and 
fee-collection scheme have been in place for two years. An initial evaluation showed that refugees are capable of contributing, albeit modestly, to covering part of the cost of the health units. They have also shown willingness to decide how the fees they collect are used. In Baluchistan, the refugees themselves requested that women doctors behired as they realized that this would encourage women and children to make use of the service.

\section{Life for the Refugees in Iran}

To its great credit, and in marked contrast to many other refugee-hosting nations, Iran did not shovel the Afghans into squalid camps. Instead, it allowed them tobeabsorbed intolocal communities-a method preferred by UNHCR, but one which few governments are politically or economically willing to undertake.

The Afghans in Iran received heavily subsidized food, health and education packages and many refugees, including women, found local employment. That has had at least one unintended effect: normally cloistered females became exposed to the workplace and education for the first time but, ironically, this may make it much more difficult for them to resettle in traditional Afghan society if and when they eventually return home.

As in Pakistan, the initial welcome given to the Afghans when they fled the might of the Soviet army in the 1980s has also worn thin in Iran. The Iranian government hoped that, under a repatriation agreement signed with UNHCR in 1992, most refugees would have returned within three years. Instead, the rise of the Taliban in Afghanistan appears to have halted repatriation from Iran altogether-at a time when Iran's economy has been suffering a significant downturn.

As a result of these developments, the original freedoms of the Afghans in Iran have been somewhat circumscribed. Movement within the country has becomemore restricted, and Afghans have been increasingly confined to designated residential areas in cities and towns. The authorities became more strict about identity documents, and expelled a number of undocumented Afghans whom they donot consider as bona fide refugees. Some social benefits have been trimmed or cut altogether (Wilkinson 1997,15). The refugees generally work in basic jobs such as construction, agriculture and embroidery. For years, refugees helped boost a robust economy, because of their low salaries and willingness to work long hours. But even in these fields, work is more restricted and difficult to find these days-resulting in a backlash from ordinary Iranians, who are themselves suffering increased unemployment. The murder of eight Iranian diplomats and a journalist during the Taliban take-over of Mazar-i-Sharif, and the subsequent military tension between Iran and the Taliban, is likely to increase public hostility towards the refugees.

\section{The Struggle to Educate Females in Pakistan}

In the 1980s, aid agencies fought a largely unsuccessful battle to establish femaleeducation. One problem was that and North-West Frontier Province (NWFP), where the refugees are located, is also extremely low. Another was that by congregating large numbers of rural Afghans-most of whom originated from small villages where everyone was part of the same extended family - in large refugee villages, the practice of purdah was reinforced. Parents were more afraid to let their daughters out of the female literacy rate in Baluchistan

the high-walled family compound into the company of strangers.

The educational situation across the border in Afghanistan itself is, of course, even worse. Back in 1993, Afghanistan had the world's fourth lowest literacy rate for females in the world (1993 figures cited in UNDP 1996) and the lowest adult female-to-male literacy ratio anywhere (1995 figures cited in UNICEF 1997). As a result of rigid enforcement of Taliban policies prohibiting female education and employment in the recently captured cities of Herat, Jalalabad, Kabul and Mazar-i-Sharif, the situation is unquestionably even more dire now. The loss of a large number of female teachers has also had a seriously detrimental effect on boys' education.

However, the long struggle.over refugee girls' education in Pakistan finally started to bear fruit in the late 1990s. In 1996 , out of perhaps 300,000 refugee girls under the age of 14 , a mere 7,757 were enrolled in primary schools, with an even smaller number in secondary or higher education. Scant return for 16 years of concerted effort by the international community to persuade the largely Pashtun refugee community (from which the Taliban originate) that female education is not the root of all evil. However, a year later the number had doubled to 14,668 , and in 1998 around 20,000 Afghan girls enrolled in primary schools in Pakistan-almost a three-fold increase in three years.

Table 1: Education of Refugee Children in Pakistan, 1996-98

\begin{tabular}{lrrrrrr}
\hline & \multicolumn{2}{c}{1996} & \multicolumn{2}{c}{1997} & \multicolumn{2}{c}{$1998^{*}$} \\
& \multicolumn{1}{c}{ Boys } & Girls & \multicolumn{1}{c}{ Boys } & Girls & \multicolumn{1}{c}{ Boys } & \multicolumn{1}{c}{ Girls } \\
\hline NWFP & 56,727 & 6,190 & 58,618 & 12,332 & 65,700 & 16,500 \\
Baluchistan & 5,484 & 1,299 & 5,139 & 1,948 & 6,000 & 3,000 \\
Punjab & 1,213 & 268 & 1,118 & 388 & 1,300 & 500 \\
\hline Subtotal & \multicolumn{1}{c}{63,424} & 7,757 & 64,875 & 14,668 & 73,000 & 20,000 \\
\hline Total & \multicolumn{2}{c}{71,181} & \multicolumn{2}{c}{79,543} & \multicolumn{2}{c}{93,000} \\
\hline
\end{tabular}

* Estimated final enrolment figure.

Source: "Educating Afghans: Opportunities in Exile." Factsheet produced by UNHCR Islamabad, June 1998. 
Over the same period the number of primary schools for girls in refugee villages has increased from 55 to 84, whereas the number of boys' primary schools has dropped slightly from 264 in 1996 to 254 in 1998 (reflecting a reduction in the number of refugee villages through repatriation, rather than a decline in demand) (UNHCR 1998c). In Pakistan, at least, the education gap between boys and girls is narrowing: in 1996 , the ratio of girls receiving education compared to boys was $1: 8$, whereas in 1998 it has increased to almost 1:3.

Besides trying to raise awareness, UNHCR had adopted some concrete measures in an attempt to improve the situation facing female Afghan refugees. In 1995, in collaboration with the World Food Program, UNHCR introduced a scheme that provided edible oil to refugee girls attending primary schools. The number of girls attending schools has doubled each year since then, and a similar incentive scheme has now been introduced for Afghan and Iraqi refugees in Iran. Refugees are alsoencouraged to form school commit- tees to support minor maintenance of schools in the hope that eventually they will be more involved in the provision of better quality education.

Recently, refugee women have also been given the chance to take part in non-formal education groups. The groups allow women to share their concerns regarding their own and their families' health and nutrition. While they learn basic literacy and numeracy, the female non-formal education groups gives them a culturally suitable forum to exchange views with other female refugees and female staff from relief agencies.

\section{Repatriation}

The relatively greater exposure of Afghan females in Iran to education and employment outside the home is one of several factors explaining why repatriation from Iran virtually stopped dead once the Taliban captured the western Afghan city of Herat in September 1995. By contrast, repatriation from Pakistan to Taliban-held rural areas has continued at a rate of around
100,000 a year since the Taliban completed their conquest of southern and eastern Afghanistan with the capture of the eastern city of Jalalabad in September 1996. The fact that the majority of the refugees in Iran are Dari-speakers and non-Pashtuns, whereas around 80 percent of the refugees in Pakistan are rural Pashtuns is another major factor that explains this phenomenon.

The collective optimism shown by the refugees in 1992-when 1.3 million returned from Pakistan and 300,000 from Iran in the space of six monthssoon wore off as the various mujahedeen groups set about their deadly business of destroying Kabul (which had been relatively untouched during the Soviet occupation). Nevertheless, only once since 1990 has the annual number of refugees returning from Pakistan dipped lower than 100,000 . Even the lowest annual return figure-the "mere" 87,000 who returned in 1997is a very high number when compared with other refugee repatriations around the world.

Table 2: Afghan Repatriation Statistics

\begin{tabular}{lcccccrr}
\hline From & $\begin{array}{c}\text { Pakistan } \\
\text { (assisted) }\end{array}$ & $\begin{array}{c}\text { Pakistan } \\
\text { (spontaneous) }\end{array}$ & $\begin{array}{r}\text { Pakistan } \\
\text { Subtotal }\end{array}$ & $\begin{array}{c}\text { Iran } \\
\text { (assisted) }\end{array}$ & $\begin{array}{c}\text { Iran } \\
\text { (spontaneous) }\end{array}$ & $\begin{array}{c}\text { Iran } \\
\text { Subtotal }\end{array}$ & $\begin{array}{c}\text { Grand } \\
\text { Total }\end{array}$ \\
\hline $1988 / 89$ & - & 200,000 & 200,000 & - & - & - & 200,000 \\
1990 & 63,000 & 87,000 & 150,000 & - & - & - & 150,000 \\
1991 & 174,000 & 26,000 & 200,000 & - & - & - & 200,000 \\
1992 & $1,274,000$ & - & $1,274,000$ & 7,000 & 287,000 & 294,000 & $1,568,000$ \\
1993 & 133,000 & 225,000 & 358,000 & 337,000 & 269,000 & 606,000 & 964,000 \\
1994 & 32,000 & 71,000 & 103,000 & 121,000 & 106,000 & 227,000 & 330,000 \\
1995 & 77,000 & 76,000 & 153,000 & 92,000 & 103,000 & 195,000 & 348,000 \\
1996 & 101,000 & 20,000 & 121,000 & 8,000 & 6,000 & 14,000 & 135,000 \\
1997 & 71,000 & 13,000 & 84,000 & 2,000 & - & 2,000 & 87,000 \\
1998 & $80,691^{*}$ & - & $80,691^{*}$ & $1,400^{+}$ & - & $1,400 *$ & 82,000 \\
\hline Total & $2,006,000$ & 718,000 & $\mathbf{2 , 7 2 4 , 0 0 0}$ & 569,000 & 771,000 & $\mathbf{1 , 3 4 0 , 0 0 0}$ & $\mathbf{4 , 0 6 4 , 0 0 0}$ \\
\hline
\end{tabular}

* From 1 January 1998 to 31 September 1998. +From 1 January 1998 to 31 August 1998.

Some totals may not add up due to rounding.

Source: "Afghan Refugee Statistics." Update produced periodically by UNHCR Islamabad, October 1998.

Refuge, Vol. 17, No. 4 (October 1998) 


\section{The Effect of Virtual Pariahdom}

By October 1998, only a few months after the four millionth Afghan went home, the situation was starting to look distinctly bleak for other refugees wishing to repatriate. With the Taliban and much of the international community locked into an increasingly solidifying impasse, and Afghanistan rapidly heading for international pariah status, funding for refugee repatriation had dried up altogether. Despite the fact that Afghans, once again, were the largest returnee group anywhere in the world in 1998 - with 80,000 having gone back by the time the United States fired its cruise missiles at the Bin Laden training camps-UNHCR's repatriation program was effectively bankrupt (UNHCR 1998f).

Afghan repatriation had become a very difficult subject to "sell" in distant donor capitals. Wasn't this the country that was hosting the world's most wanted terrorist? Hadn't itjust been hit by cruise missiles? Hadn't all international UN staff been evacuated? Wasn't it the largest producer of heroin on the planet? Didn't it have a huge Iranian army looming on its border? Wasn't news of an apparently large-scale ethnicmassacre of Hazaras in the northern city of Mazar-i-Sharif starting to arrive via new refugees arriving in Pakistan? Didn't the regime that now controlled about 90 percent of Afghanistan maintain unacceptable discriminatory policies against women? Wasn't virtually every article of the Universal Declaration of Human Rights being violatedand this during the Declaration's 50th Anniversary year? And UNHCR wants money to repatriate people to this place?

The answer is yes. While refugees wish to return - and many of those currently in Pakistan still want to-it is wrong for the international community to say it knows better than they do, and stick unnecessary obstacles in their path. It is no more strange that refugees still wish to go back now than it was when a full-scale war was tearing Kabul apart. That is because those who want to return are not necessarily directly affected by all the concerns upsetting much of the outside world. The refugees who are trying to go back are from rural parts of southern and eastern Afghanistan, where life has been relatively peaceful and where the Taliban's controversial social policies are far less rigidly enforced than in the cities.

Afghan refugees base their decision on their own knowledge about the situation in their home area. They take the wider political, military, social and economic considerations into account, but it is local conditions, particularly security, that are of the most importance to them. Educated professionals, especially women, are not returning to cities such as Kabul and Herat; people from the north and west are not returning; Hazaras are certainly not returning. For them, conditions are far from attractive at this point.

But many refugees from rural farming communities in the south and the east (who comprise about three-quarters of the 1.2 million refugees still in Pakistan) want to go back (UNHCR 1998e). And some of them want to go back now. After as many as 20 years in exile, they are worried that if they don't gobacksoon, they may not gobackat all. The generation that knew a peaceful existence in Afghanistan prior to the 1979 Soviet invasion is ageing fast. Already there are many young Afghan adults who have never set foot inside their home country and many others who only have very dim childhood memories of life in Afghanistan.

If the repatriation program really grinds to a halt because of a lack of funding, it would be unprecedented in the history of refugees. It would mean that the international community had washed its hands of the largest refugee group in the world. Abandoning the Afghan refugees now will do nothing to improve regional stability and risks further undermining the international refugee protection system which has been undersomuch pressure elsewhere in recent years. And there's also a question of fundamental fairness to those who actually want to return.

Another factor the donor community maybe failing to take intoaccount is that returnees can be an important engine of social change. Repatriating refugees take not only their personal baggage and roof beams home with them, but also the ideas, skills and habits they have picked up while in exile. In particular, refugees in both Iran and Pakistan have come to value education and health facilities-for both males and females-during their long period in exile. The new assisted group repatriation scheme that UNHCR began implementing in 1997 is targeting particular groups of refugees in Pakistan who express a desire to return home but are prevented from doing soby a number of obstacles. Many groups have been stressing the importance of education and are confident that if international agencies give them the necessary support, they will be able to set up girls' as well as boys' schools, particularly in remote rural areas where the Taliban authorities are less inclined and able to interfere in everyday matters.

Just as it was starting to gather momentum, the group repatriation scheme effectively ground to a halt in August 1998. The basic assistance package given to other returning refugees was also threatened with a complete shutdown. The engine of much-needed social change inside Afghanistan was switched off, firstly by the cruise missiles and then by the lack of funds. In some cases, UNHCR was struggling to complete projects promised to refugee groups that had returned earlier in the year. Another eight groups eager to return in the autumn were informed by UNHCR in late September that they would no longer be able to do so before 1999. The scheme depends very much both on its own momentum and on its credibility with the refugees. Because of the lack of funding, and the other crises affecting Afghanistan, the momentum had stopped in its tracks, and the credibility was inevitably damaged. The funding prognosis for 1999 was not looking at all good either.

The Afghans still represent almost one-fifth of all refugees in the world today. It would be a tremendous admission of failure to abandon the only viable solution to their prolonged ColdWar-induced exile. 


\section{References}

British Agencies Afghanistan Group. 1996. "Living in Exile." Report on a study of economic coping strategies among Afghan Refugees in Pakistan. The [British] Refugee Council, London, December.

__. 1997. "Return and Reconstruction." Report on a study of economic coping strategies among farmers in Farah Province, Afghanistan. The [British] Refugee Council, London, July.

Colville, Rupert. 1997. “The Biggest Caseload in the World." Refugees, no. 108.

Maley, William, ed. 1998. Fundamentalism Reborn?: Afghanistan and the Taliban. Lahore: Vanguard Books.

Malha, Monique. 1997. "Eighteen Years in Exile: The Situation of Refugees in Pakistan." Liberal Times: A Forum for Liberal Policy in South Asia V, no. 1.

Marsden, Peter. 1998. The Taliban: War, Religion, and the New Order in Afghanistan. London: New York: Zed Books.

United Nations Children Fund (UNICEF). 1997. The State of the World's Children, 1997. Oxford; New York: Oxford University Press.

United Nations Development Program (UNDP). 1996. Human Development Report, 1996. Oxford; New York: Oxford University Press.

United Nations High Commissioner for Refugess (UNHCR). 1997. Refugees, no. 108, "Afghanistan: The Unending Crisis."

_. 1998a. "Afghan Refugee Statistics." Statistical update produced several times a year, UNHCR Islamabad.

- 1998b. "Pakistan." Factsheet, UNHCR Islamabad, 12 April.

-1998c. "Educating Afghans: Opportunities in Exile." Factsheet, UNHCR Islamabad, June.

-1998d. "Four Millionth Afghan Refugee Returns Home, 2.6 Million Remain in Exile." Press Release, UNHCRIslamabad, 30 June.

_. 1998e. "Note on the First Six Months of Assisted Voluntary Repatriation of Afghan Refugees from Pakistan in 1998." UNHCR Islamabad, July.

-1998f. Afghan Refugee Bulletin. A draft of the first issue. To be published by UNHCR Islamabad in December.

Wilkinson, Ray. 1997. "An Iranian Surprise." Refugees, no. 108.

World Food Program (WFP). 1998. "Internal Project Document for Extending Food Assistance to Newly Arrived Afghan Refugees in Pakistan." Rome, July. ם

\section{A SJ DIII: \\ A Moral Dilemma \\ By W. Gunther Plaut}

Toronto: York Lanes Prese, 1995

Is6N 1-55014-229,9, 192 pages, indexed; $\$ 19.90$

Eresy year the refugee landscape changes, but only in that more problems areetdded, fewer are solved, and all become constantly more urgent. Fuelled by the explosion of the world's population, the quest for anyluin is one of the rnost pressing problems of our age. Refuge-rooeivigg nationo-located frequently, but by no means exclustrely, in the Westem world - have to respond to masses of humanity searching for new livable homes. Fuman compassion for there refuges can be found every where, but so can xertophobia and the destre to pregerve one's nation, economic well being, and cultural integity. The clash between these impulses represents one of the great dile mmas of our time and is the subject of Plaur's study: In exploring the provides a far-ranging inquiry into the human condition.

The book presents political, ethnic, philosophical, religious, and sodilogical arg iments, and deals withsomeof the most troublesome and heatbrealing conflics in the news.

Contents: The Tsokes; Questions Without Answers; Definitions: Religion, Natural Law, and Hospitality; A Look at History; Some Ethical Oabtrons; Through the Lens of Sociobiologr, Community and Thdividual, Contended Rights: To Leave, Retum, Remain;

The Prectest Retugess in Afrca; Four Asian Lands; Climpses of

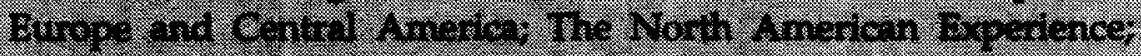
The Smatiany Movement; A Final Look BAbliography; Index.

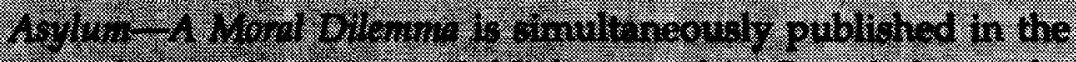

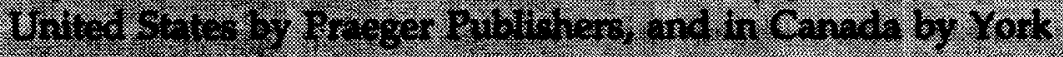
Lanes reses. 